\title{
Electrically Evoked Synaptosomal Amino Acid Transmitter Release in Human Brain in Alcohol Misuse
}

\author{
Sheng-Wen Kuo Peter R. Dodd \\ School of Chemistry and Molecular Biosciences, University of Queensland, Brisbane, Qld., Australia
}

\section{Key Words}

Brain damage $\cdot$ Excitotoxicity $\cdot$ Cirrhosis

\begin{abstract}
Severe chronic alcohol misuse leads to neuropathological changes in human brain, with the greatest neuronal loss in the dorsolateral prefrontal cortex. In this region, $\mathrm{GABA}_{A}$ receptors are selectively upregulated, and show altered subunit expression profiles only in alcoholics without comorbid disease, whereas glutamate ${ }_{\text {NMDA }}$ subunit expression profiles are selectively downregulated only in alcoholics with comorbid cirrhosis of the liver. To determine whether these outcomes might be conditional on synaptic transmitter levels, evoked release was studied in well-characterized synaptosome suspensions preloaded with $\left.\mathrm{L}-{ }^{3} \mathrm{H}\right]$ glutamate and $\left[{ }^{14} \mathrm{C}\right] \mathrm{GABA}$ and stimulated electrically $( \pm 10 \mathrm{~V}$ contiguous square waves, $0.4 \mathrm{~ms}, 100 \mathrm{~Hz}, 1.5 \mathrm{~min}$ ) with and without $\mathrm{Ca}^{2+}$. Stimulation elicited brief peaks of both radioisotopes that were larger in the presence of $\mathrm{Ca}^{2+}$ ions $(p<0.01)$. A repeat stimulus evoked a second, smaller $(p<0.01)$ peak. $\mathrm{Ca}^{2+}$-dependent $\mathrm{L}-\left[{ }^{3} \mathrm{H}\right]$ glutamate release, but not $\left[{ }^{14} \mathrm{C}\right] \mathrm{GABA}$ release, was higher overall in alcoholics than in controls $(p<0.05)$. With comorbid cirrhosis, L-[ $\left.{ }^{3} \mathrm{H}\right]$ glutamate release showed a graded response, whereas $\left[{ }^{14} \mathrm{C}\right] \mathrm{GABA}$ release was lowest in noncirrhotic alcoholics. Release patterns did not differ be-
\end{abstract}

tween cortical regions, or between males and females. Neither age nor postmortem interval was a significant confounder. The released transmitters may differentially alter receptor profiles on postsynaptic cells.

Copyright $\odot 2011$ S. Karger AG, Basel

\section{Introduction}

Severe chronic alcohol misuse has neuropathological, cognitive, and behavioral effects on human subjects, but the underlying mechanisms are not well understood [1]. Selective neuronal loss in the cerebral cortex is mostly confined to the dorsolateral prefrontal gyrus $[2,3]$. When chronic alcoholic subjects are compared with nonalcoholic controls, this region expresses $\mathrm{GABA}_{\mathrm{A}}$ receptors with a different subunit profile, consistent with reduced protection against excitoxicity [4-6]. Microarray analyses of over 50,000 mRNA transcripts have been performed on dorsolateral prefrontal cortex tissue samples from chronic alcoholics and controls [7-9]. Transcripts coding for several synaptic proteins differed by $40 \%$ (1.4fold) or more between the case groups, suggesting that synaptic transmission may be affected by chronic alcohol intake.

\section{KARGER}

() 2011 S. Karger AG, Basel

Fax +41613061234 E-Mail karger@karger.ch www.karger.com www.karger.com/nsg
Peter R. Dodd

School of Chemistry and Molecular Biosciences

Molecular Biosciences Building 7, Cooper Road

University of Queensland St Lucia campus, Brisbane, QLD 4072 (Australia)

Tel. +61 73365 3364, E-Mail p.dodd@uq.edu.au 
Synaptosomes prepared from autopsy brain show good rates of respiration stimulable by depolarization [10, 11], indicative of the generation of a membrane potential $[12,13]$. Synaptosome profiles contain mitochondria and vesicles, which shows that they are pinched off rather than burst and resealed: probable glial fragments are largely empty [10], and indices of glial function are markedly reduced as compared with neuronal activities [14]. Synaptosomes from human autopsy brain can be subfractionated to prepare functional synaptic vesicles [15]; both plasma-membrane and vesicular transport functions persist for long periods post-mortem $[14,15]$. Alcoholics without comorbid disease express $\mathrm{GABA}_{\mathrm{A}}$ receptors in the dorsolateral prefrontal cortex that differ from controls in pharmacology and subunit profile, consistent with reduced protection against excitotoxicity $[4,6]$. In alcoholics with cirrhosis, $\mathrm{GABA}_{\mathrm{A}}$ sites are little affected but glutamate-NMDA receptors markedly altered [16]. It is problematic to model regional cortical pathology in lisencephalic animals, and it is difficult to induce cirrhosis experimentally with alcohol in laboratory animals, even non-human primates ( $\sim 20 \%$ of baboons develop fibrosis after 5 years on a diet in which $50 \%$ of their calorific intake is ethanol) [17].

In previous work, we developed a release protocol for amino acid transmitters from autopsy brain using chemical stimulation of synaptosomes [18]. However, the released amino acids originated predominately from the cytoplasmic compartment, because the $\mathrm{Ca}^{2+}$-dependent component was minor. Changing the electrochemical gradient across the plasma membrane will reverse plasma-membrane carriers [19]. In contrast, electrical stimulation induces $\mathrm{Ca}^{2+}$-dependent exocytosis via rapid transmembrane fluxes in potential that mimic physiological inputs [20].

The present study investigated the use of electrical stimulation to trigger transmitter release from synaptosomes prepared from human autopsy brain tissue. The aim was to evaluate the effects of chronic alcohol misuse on the dynamics of neurotransmitter release, to contribute to an understanding of the pathogenesis of alcoholrelated brain damage. Preliminary reports of the work have been presented $[21,22]$.

\section{Materials and Methods}

Human Tissue Preparation

Unfixed frozen tissue samples were obtained from the Queensland Brain Bank and the NSW Tissue Resource Centre in collaboration with the Australian Brain Bank Network. All cases had a full autopsy including macroscopic and microscopic examination of the brain and liver. Informed written consent was obtained for all autopsies, which were performed by authorized pathologists. The University of Queensland Medical Research Ethics Committee approved the consent, tissue retrieval, and research protocols (clearance No. H/09/Biochem/NHMRC/98). For each case, information on general health, diet, alcohol intake, medication, and the presence of alcohol-related diseases such as cirrhosis of the liver was available from medical records and autopsy reports. No subject had clinical or pathological evidence of neurological or psychiatric disease (apart from alcoholism) prior to death. According to the reports, no patient was a polysubstance or intravenous drug user, and none had been prescribed neuroactive medication. Cases were divided into groups depending on alcohol intake and the presence of complicating disease. Full liver pathology, which differentiated cirrhotic and noncirrhotic participants, was available in every case. Controls were teetotal or had low alcohol intake ( $<20 \mathrm{~g}$ of ethanol per day), whereas alcoholics consumed more than $80 \mathrm{~g}$ of ethanol per day. All alcoholics had been misusing ethanol for most of their adult lives, and in almost all instances where information was available had been drinking up until the time of death: mean alcohol-misuse durations were 38 years for noncirrhotic and 40 years for cirrhotic alcoholics. Full consumption details were not available in every case, but where they were, the average daily consumption by alcoholics without comorbid disease was 13 standard drinks (130 g ethanol); it was 25 standard drinks (250 g ethanol) for alcoholics with cirrhosis. At autopsy, one hemisphere was fixed in formalin for pathological examination, while the other was dissected in the mortuary to minimize the delay to cryoprotection. Tissue samples $\left(1-5 \mathrm{~cm}^{3}\right)$ were dissected from various cortical regions, placed individually into small plastic bags, and immediately immersed in ice-cold $0.32 \mathrm{M}$ sucrose. The samples were brought to the laboratory, frozen slowly, and stored at $-80^{\circ} \mathrm{C}$ until required. These procedures are optimal for the preservation of tissue components [11]. Clinical details and causes of death are listed in table 1.

\section{Synaptosome Preparation}

The method previously described was used with minor modifications [23]. In brief, tissue samples were rapidly thawed in $0.32 \mathrm{M}$ sucrose at $37^{\circ} \mathrm{C}$, immediately placed in $10 \mathrm{vol}$. of ice-cold $0.32 \mathrm{M}$ sucrose, and homogenized with a motor-driven Teflonglass homogenizer at $500 \mathrm{rpm}$ for 8 strokes. The homogenate was centrifuged at 1,400 $\mathrm{g}$ for $5 \mathrm{~min}$ (Beckman J2-21 centrifuge; JA20 rotor; Beckman Coulter P/L, Gladesville, N.S.W., Australia). The supernatant was removed, overlaid onto a cushion of $1.2 \mathrm{M} \mathrm{su}-$ crose, and centrifuged at 33,000 $\mathrm{g}$ for $30 \mathrm{~min}$. The interface material was removed and diluted with ice-cold $0.32 \mathrm{M}$ sucrose to the original suspension volume. This suspension was layered onto a cushion of $0.8 \mathrm{M}$ sucrose and centrifuged at $33,000 \mathrm{~g}$ for $30 \mathrm{~min}$. The supernatant was aspirated and discarded, and the pellet dispersed in ice-cold $\mathrm{Ca}^{2+}$-free perfusion buffer.

\section{Perfusion Buffer}

Two Krebs/HEPES perfusion buffers were used: (1) $\mathrm{Ca}^{2+}$-containing buffer, PBC: $10 \mathrm{mM}$ HEPES, $118 \mathrm{mM} \mathrm{NaCl}, 4.8 \mathrm{mM} \mathrm{KCl}$, $1.2 \mathrm{mM} \mathrm{MgSO}_{4}, 1.2 \mathrm{mM} \mathrm{KH}_{2} \mathrm{PO}_{4}, 2.5 \mathrm{mM} \mathrm{CaCl}_{2}, 10 \mathrm{mM}$ glucose, pH 7.4; gassed with $95 \% \mathrm{O}_{2} / 5 \% \mathrm{CO}_{2}$; (2) $\mathrm{Ca}^{2+}$-free buffer, $\mathrm{PB} 0$ : same composition as $\mathrm{PBC}$, except that $\mathrm{CaCl}_{2}$ was omitted and 0.5 mM EGTA included. 


\section{Preloading Labeled Transmitter}

To determine the optimal time for transmitter uptake, $10 \mu \mathrm{Ci}$ of $\mathrm{L}-\left[{ }^{3} \mathrm{H}\right]$ glutamate or $\left[{ }^{14} \mathrm{C}\right] \mathrm{GABA}($ each $1 \mu \mathrm{M})$ was added to a synaptosome preparation $(\sim 1 \mathrm{mg}$ protein $/ \mathrm{ml}$ in $\mathrm{PBC})$. The suspension was divided into subsets that were each incubated at $37^{\circ} \mathrm{C}$. At various time points, the assay was terminated by filtration onto Whatman GF/B filters, followed by three rapid washes with icecold $0.9 \% \mathrm{NaCl}$ to remove incubation medium, using a cell harvester (Brandel M24, Gaithersburg, Md., USA). Filters were airdried and placed into scintillation vials to which $4 \mathrm{ml}$ of scintillation fluid was added (Packard Emulsifier-Safe; PerkinElmer P/L, Glen Waverley, Vic., Australia); radioactivity was determined in a scintillation counter with on-board quench correction. Time courses of tracer uptake are shown in figure $1 \mathrm{a}, \mathrm{b}$. It may be seen that the uptake of labeled neurotransmitter reached a maximum at $20 \mathrm{~min}$. This incubation time was chosen for subsequent studies of release.

In the optimized protocol for preloading neurotransmitters, synaptosomes were resuspended in prewarmed PB0 $(0.5 \mathrm{ml}$; final protein concentration $1 \mathrm{mg} / \mathrm{ml}$ ) and incubated with $1 \mu \mathrm{M}$ of $\mathrm{L}-\left[{ }^{3} \mathrm{H}\right]$ glutamate or $1 \mu \mathrm{M}$ of $\left[{ }^{14} \mathrm{C}\right] \mathrm{GABA}$ for $20 \mathrm{~min}$ at $37^{\circ} \mathrm{C}$, then placed on ice for $10 \mathrm{~min}$ before use.

\section{Electrically Evoked Release}

Aliquots of preloaded synaptosomes $(160 \mu \mathrm{l})$ were transferred to the chambers of the superfusion apparatus (Brandel S600) housed in a $37^{\circ} \mathrm{C}$ room. A feature of the apparatus is that the cylindrical chambers are arrayed vertically such that buffer enters from below and leaves at the top, with both entry and exit ports protected by retaining screens. This ensures that the synaptosome suspension is constantly gently irrigated to prevent it from compacting at the base of the chamber, which is critical with these delicate subcellular organelles. Ring electrodes are fitted at the top and bottom of the perfusion chambers, which have minimal dead-space to ensure optimal response to stimulation. The chambers were perfused at a rate of $0.5 \mathrm{ml} / \mathrm{min}$ with perfusion buffer; the buffer reservoir was constantly gassed with $95 \% \mathrm{O}_{2} / 5 \% \mathrm{CO}_{2}$ throughout the experiment. After a 20-min washout, fractions of perfusate were collected every $1.5 \mathrm{~min}$ on the built-in collector. Release of tracer was trigged by stimuli applied to the chamber electrodes from an electrical stimulator (manufactured in the SCMB workshop). Current was monitored routinely with a Digital Multimeter (Digitech QM 1535; Jaycar Electronics, Woolloongabba, Qld., Australia). Electrical stimulation was applied as contiguous rectangular pulses of alternating positive and negative polarity, $0.4 \mathrm{~ms}$ duration, $100 \mathrm{~Hz}$. By immediately reversing the polarity of the stimulus, the duration of depolarization event and the risk of anodic corrosion of the electrodes are both minimized.

At the end of the session, the perfusion buffer was replaced with $0.25 \mathrm{M}$ perchloric acid $\left(\mathrm{HClO}_{4}\right)$ to release residual radioactivity from the tissue. This final sample was neutralized with $\mathrm{KOH}$ to precipitate $\mathrm{KClO}_{4}$ and clarified by brief centrifugation before further processing. Each fraction was mixed with $4 \mathrm{ml}$ of scintillation fluid for the determination of radioactivity, as described above.

\section{Data Analysis}

Data are expressed as a fractional release rate (FRR) in which the amount of radioactivity in each fraction was divided by the synaptosomal content of radioactivity prior to its collection. The
Table 1. Case information on subjects

\begin{tabular}{|c|c|c|c|c|}
\hline No. & Sex & $\begin{array}{l}\text { Age } \\
\text { years }\end{array}$ & PMI, h & Cause of death \\
\hline \multicolumn{5}{|c|}{ Nonalcoholic subjects } \\
\hline 1 & $\mathrm{~F}$ & 66.58 & 56.77 & Peripheral ischemia \\
\hline 2 & $\mathrm{~F}$ & 75.97 & 24.43 & Heart disease \\
\hline 3 & $\mathrm{~F}$ & 81.22 & 21.43 & Intracranial hemorrhage \\
\hline 4 & $\mathrm{~F}$ & 43.17 & 18.50 & $\begin{array}{l}\text { Pulmonary embolism, venous } \\
\text { thromboses }\end{array}$ \\
\hline 5 & $\mathrm{~F}$ & 57.42 & 9.75 & Cardiac failure \\
\hline 6 & $\mathrm{~F}$ & 87.09 & 21.50 & Pulmonary edema, cardiac failure \\
\hline 7 & $\mathrm{~F}$ & 32.86 & 48.42 & $\begin{array}{l}\text { Pulmonary thromboembolism, } \\
\text { breast carcinoma }\end{array}$ \\
\hline 8 & $\mathrm{~F}$ & 78.36 & 4 & Ischemic heart disease \\
\hline 9 & M & 70.57 & 26 & $\begin{array}{l}\text { Cardiac and renal failure, broncho- } \\
\text { pneumonia }\end{array}$ \\
\hline 10 & M & 86.42 & 15.15 & $\begin{array}{l}\text { Myocardial infarction, ischemic } \\
\text { heart disease }\end{array}$ \\
\hline 11 & M & 85.12 & 24.50 & Pneumonia, ischemic heart disease \\
\hline 12 & M & 82.80 & 46.83 & Cardiorespiratory arrest \\
\hline 13 & M & 24 & 24 & Electrocution, myocardial ischemia \\
\hline 14 & $\mathrm{M}$ & 37 & 11 & Pulmonary embolism \\
\hline \multicolumn{2}{|c|}{ Average } & $65 \pm 22$ & $25 \pm 15$ & \\
\hline
\end{tabular}

Alcoholic subjects

Alcoholics without comorbid disease

$\begin{array}{rllll}1 & \text { F } & 70 & 17 & \text { Cardiac arrhythmia } \\ 2 & \text { F } & 64 & 58 & \text { Peritonitis, pneumonia } \\ 3 & \text { F } & 28.22 & 49.42 & \text { Pneumonia } \\ 4 & \text { F } & 44.99 & 16 & \text { Alcohol-related disorder } \\ 5 & \text { F } & 46 & 27 & \text { Pulmonary congestion and epilepsy } \\ 6 & \text { F } & 46 & 5 & \text { Respiratory distress syndrome } \\ 7 & \text { M } & 18.77 & 30.50 & \text { Alcohol toxicity } \\ 8 & \text { M } & 59.08 & 15 & \text { Hanging } \\ 9 & \text { M } & 51.24 & 7.50 & \text { Acute pneumonia, cardiac failure } \\ 10 & \text { M } & 29.15 & 24.50 & \text { Pulmonary edema, cardiomyopathy } \\ 11 & \text { M } & 56 & 48 & \text { Renal failure, ischemic heart disease } \\ 12 & \text { M } & 66.99 & 46 & \text { Pancreatic carcinoma } \\ 13 & \text { M } & 66 & 11.5 & \text { Renal failure, chronic anemia } \\ \text { Average } & 50 \pm 16 & 27 \pm 18 & \end{array}$

Cirrhotic alcoholics

\begin{tabular}{|c|c|c|c|}
\hline $\mathrm{F}$ & 74.62 & 20.25 & Renal failure \\
\hline $\mathrm{F}$ & 37 & 14 & Not stated \\
\hline M & 55.55 & 58.08 & $\begin{array}{l}\text { Multisystem organ failure due to } \\
\text { pulmonary hypertension }\end{array}$ \\
\hline M & 63.40 & 26.5 & Upper gastrointestinal hemorrhage \\
\hline $\mathrm{M}$ & 48.48 & 14.67 & Renal failure \\
\hline Average & $56 \pm 14$ & $27 \pm 18$ & \\
\hline
\end{tabular}

Average values for age and PMI are means \pm standard deviation. 
Fig. 1. Transmitter preloading and release paradigms. a L- $\left[{ }^{3} \mathrm{H}\right]$ glutamate uptake time course. $\mathbf{b}\left[{ }^{14} \mathrm{C}\right] \mathrm{GABA}$ uptake time course. Radiolabeled transmitters were each applied to synaptosome suspensions at $1 \mu \mathrm{M}$ as described in the 'Methods' section. Uptake of both substrates reached a maximum by $\sim 20 \mathrm{~min}$; this time was used for preincubations in assays of release. Representative time courses are shown; each assay was performed three times with similar results. Ordinates show radioactivity accumulated in the synaptosome residue obtained at each time point ('Methods'). The drop in $\mathrm{L}-\left[{ }^{3} \mathrm{H}\right]$ glutamate content after 20 min may have come about because its concentration in the medium was sufficient to activate presynaptic receptors and elicit rerelease of vesicular transmitter. c The standard superfusion paradigm employed showing the application and duration of stimuli S1 and S2 and how the AUC values of the evoked release peaks $\mathrm{P}_{1}$ and $\mathrm{P}_{2}$ were determined. FRR was calculated as described in the 'Methods' section. The delay from initiation of stimulation to the peak of release reflects the dead space in the collection lines. d Average sizes of release peaks. Mean AUC values for $\mathrm{P}_{1}$ and $\mathrm{P}_{2}$ are shown, averaged across both areas, all subjects, the two transmitters, and both $\mathrm{Ca}^{2+}$ concentrations; the order of perfusion with the two $\mathrm{Ca}^{2+}$ concentrations was randomized across experiments. To rectify the non-normal distribution of AUC values, a Kleczkowski transformation [24] was applied (see 'Methods'), given by $\kappa(\mathrm{A})_{i j}=\log _{e}\left(\mathrm{~A}_{i j}+14.919\right)$, where $\mathrm{A}_{i}$ is the AUC of the $i^{t h}$ peak elicited by stimulus $S_{j}$. An ANOVA was performed on the transformed values; least-squares mean and SEM values from the ANOVA were converted back to the FRR scale for presentation. $\mathrm{P}_{1}$ AUC averaged $46 \%$ of $\mathrm{P}_{2}$ AUC (main effect for peak significant, $\mathrm{F}_{1,30}=$ 221.928, p < 0.001). $\mathbf{\square}=1$ st release peak; $\square=2$ nd release peak; values are means \pm SEM on the FRR scale. e Comparison of $\mathrm{L}-\left[{ }^{3} \mathrm{H}\right]$ glutamate and $\left[{ }^{14} \mathrm{C}\right] \mathrm{GABA}$ release. Overall, L- $\left[{ }^{3} \mathrm{H}\right]$ glutamate release was about double $\left[{ }^{14} \mathrm{C}\right] \mathrm{GABA}$ release (main effect for amino acid, $\left.\mathrm{F}_{1,30}=233.069, \mathrm{p}<0.001\right)$. The $\mathrm{L}-\left[{ }^{3} \mathrm{H}\right]$ glutamate $\mathrm{P}_{2}$ AUC averaged $39 \%$ of the corresponding $\mathrm{P}_{1} \mathrm{AUC}$, whereas $\left[{ }^{14} \mathrm{C}\right]$ GABA $\mathrm{P}_{2}$ AUC averaged $56 \%$ of the $\left[{ }^{14} \mathrm{C}\right]$ GABA $P_{1}$ AUC (peak $\times$ amino acid interaction significant, $\left.F_{1,30}=82.016, p<0.001\right)$. Key as in d.
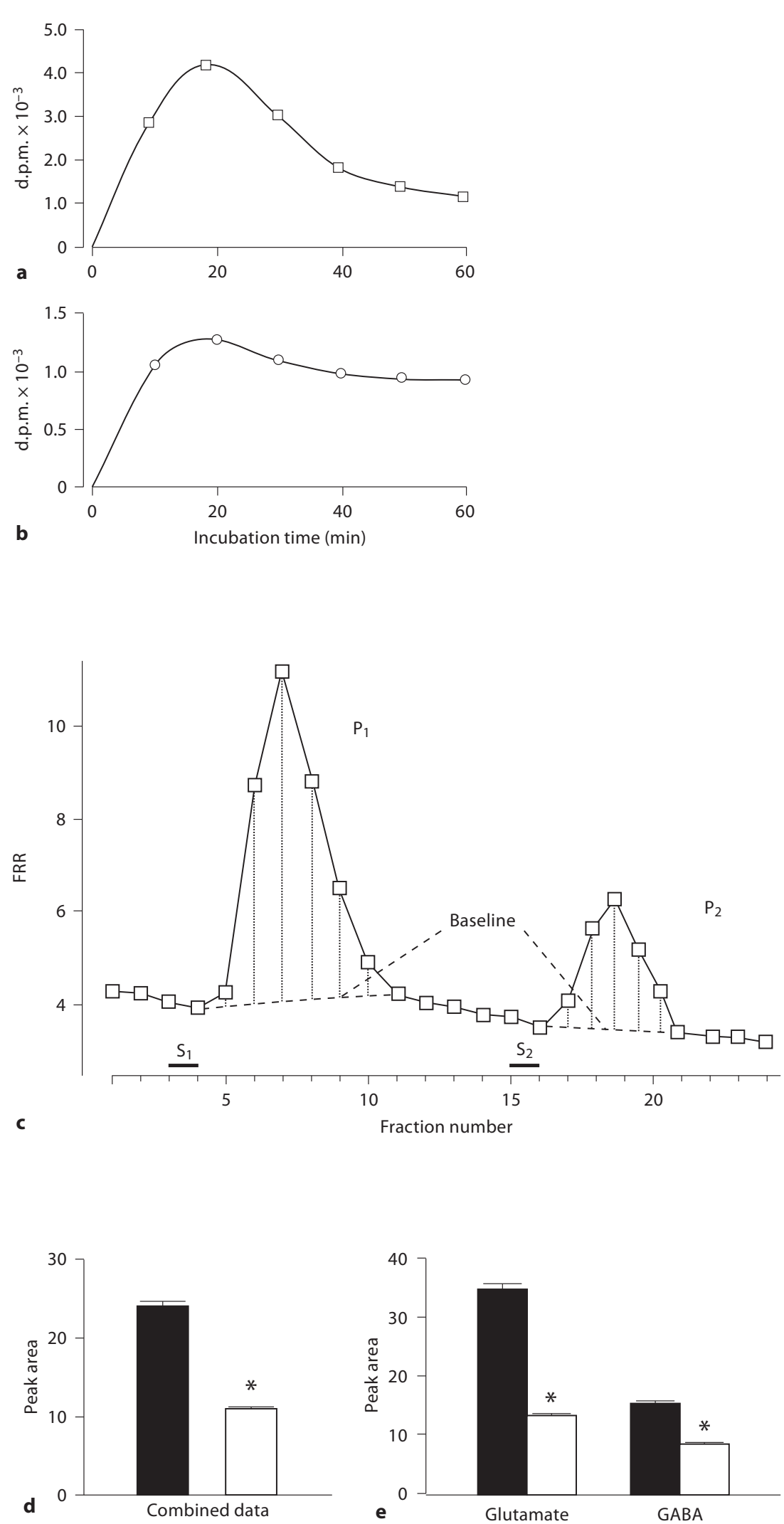
synaptosomal content of radioactivity was calculated by summing the radioactivity released in all subsequent fractions, including the radioactivity released by $\mathrm{HClO}_{4}$.

FRR for fraction $x_{i}=\frac{\mathrm{dpm} \text { in fraction } x_{i}}{\mathrm{dpm} \text { in fraction } x_{i}+\text { all subsequent fractions }}$

Synaptosomes were electrically stimulated during the collection of the 4 th $\left(\mathrm{S}_{1}\right)$ and 16th $\left(\mathrm{S}_{2}\right)$ fractions (fig. 1c). This elicited the release of brief pulses of radioactivity, signified as $\mathrm{P}_{1}$ and $\mathrm{P}_{2}$ (fig. 1c). When stimuli were applied, the sum of the increased FRR values minus the interpolated baseline values gave the 'stimulusevoked release peak' as the area under the curve (AUC; fig. 1c-e). To balance the order of stimulation in buffers containing the two $\mathrm{Ca}^{2+}$ ion concentrations, duplicate samples of synaptosomes were superfused in parallel (the apparatus has six superfusion chambers that can be fed independently from different buffer reservoirs).

Peak AUC data were compiled and plotted using the computer programs Excel (Microsoft P/L, North Ryde, N.S.W., Australia) and GraphPad Prism (Graphpad Software, San Diego, Calif., USA). Statistical analysis was performed with the Statistica v9.0 (StatSoft, Tulsa, Okla., USA) and SPSS v18.0 (IBM, Somers, N.Y., USA) software packages. Preliminary tests showed that AUC data distribution deviated significantly from normal in the number of instances. Normal probability plots were significantly nonlinear (Shapiro-Wilks tests, $\mathrm{p}<0.01$ ), indicating a positive skewness, and plots of peak AUC values obtained at different $\mathrm{Ca}^{2+}$ concentrations were nonparallel. Kleczkowski transformations [24] stabilized the variances and generated co-parallel normal probability plots. Separate analyses were done on the $\mathrm{Ca}^{2+}$-dependent component of stimulus-coupled release (v.i.). These values were obtained by subtracting the peak AUC obtained in $\mathrm{PB} 0$ from the AUC obtained in PBC for a given transmitter and stimulus. A separate Kleczkowski transform was calculated for these difference peaks. Statistical tests were performed on transformed values; least-squares mean and SEM values were converted back to the original scale of measurement for presentation.

Following regression analysis (v.i.), age at death and postmortem interval (PMI) were tested as continuous predictors in analyses of covariance, but no term containing these factors, alone or in combination, was significant in any analysis. Moreover, the groups did not differ significantly on either factor by analysis of variance (ANOVA), and no pairwise comparison was significant $(p>0.1)$. It was thus appropriate to use ANOVAs, together with relevant post-hoc tests where necessary, to assess differences in stimulus-evoked transmitter release [25]. Exact probabilities are quoted down to $\mathrm{p}=0.001$; significance was accepted at $\mathrm{p}<0.05$.

\section{Results}

\section{Stimulus Repetition}

To demonstrate that electrically evoked release retains a key characteristic of exocytosis and did not result from compromise of the synaptic membrane, a repeat stimulus of equal strength was applied after a brief recovery period. It may be seen (fig. 1c) that the second stimulus elicited a second response peak, albeit somewhat attenuated (fig. 1d). The attenuation was more marked for glutamate than for GABA (fig. 1e).

\section{Characterization of the Electrical Stimulation Parameters}

Due to the limited availability of human tissue, only two voltage settings were tested. Because repeated stimuli led to attenuation of the release peak (above), these tests were carried out on synaptosomes that were only stimulated once $\left(\mathrm{S}_{1}\right)$. Figure $2 \mathrm{a}$, b illustrates that the size of both the $\mathrm{L}-\left[{ }^{3} \mathrm{H}\right]$ glutamate and $\left[{ }^{14} \mathrm{C}\right] \mathrm{GABA}$ release peaks was larger at $10 \mathrm{~V}$. Consistent with the present data, previous work had shown that the response elicited from rat synaptosomes by $\sim 10 \mathrm{~V}$ was maximal [26], so this intensity was selected for subsequent work. Figure $2 \mathrm{c}$, d shows the effect of varying the $S_{1}$ stimulation time on release. Doubling the duration of a 10 -volt stimulus from $1.5 \mathrm{~min}$ to 3 min did not significantly increase the AUC of the release peak. The shorter stimulation time was used in all subsequent experiments.

\section{Effect of $\mathrm{Ca}^{2+}$}

Perfusion with a physiological concentration of $\mathrm{Ca}^{2+}$ ions significantly enhanced transmitter release (fig. 3a). The mean increase was $89 \%$ overall (fig. 3 legend). $\left[{ }^{14} \mathrm{C}\right]$ GABA release was not as strongly induced by electrical stimulation in either perfusion medium (fig. 3b), and neither was the net increase due to $\mathrm{Ca}^{2+}$ as great (fig. 3b, legend). The $\mathrm{Ca}^{2+}$-dependent peak size was used as an index of synaptic-vesicle exocytosis.

\section{Effects of Age and PMI}

The effects of age at death and PMI on $\mathrm{Ca}^{2+}$-dependent stimulus-coupled transmitter release were assessed by linear regression. Separate analyses were performed on transforms of the $\mathrm{P}_{1}$ and $\mathrm{P}_{2}$ difference peaks. The only significant regression was $\mathrm{P}_{2} \mathrm{~L}-\left[{ }^{3} \mathrm{H}\right]$-glutamate release on age (fig. $3 c$, legend). It may be seen (fig. $3 c-f$ ) that the $P_{1}$ transforms for both transmitters gave quite shallow and nonsignificant slopes against either factor. Analysis of covariance can be problematic if the slopes of regressions on the covariate are heterogeneous [25]. In any case, covariance analyses showed that no term containing a covariate (main effect or interaction) was significant (see above). Further analyses were conducted by ANOVA on $\mathrm{P}_{1}$ difference peaks only.

\section{Chronic Alcohol Misuse and Vesicular Release}

Overall $\mathrm{Ca}^{2+}$-dependent synaptosomal release of $\mathrm{L}$ $\left[{ }^{3} \mathrm{H}\right]$ glutamate in response to electrical stimulation was 
Fig. 2. Optimization of stimuli. To minimize potential confounds, only one stimulus was applied to control synaptosomes superfused with $\mathrm{Ca}^{2+}$-containing medium. a, b Intensity. Stimulus parameters were kept constant (see 'Methods'), except that current was applied at $\pm 5 \mathrm{~V}$ (squares, dashed lines) or $\pm 10 \mathrm{~V}$ (circles, solid lines) for $1.5 \mathrm{~min}$. c, d Duration. Parameters were kept constant except that 10 -volt stimuli were applied for $1.5 \mathrm{~min}$ (circles, solid lines) or $3 \mathrm{~min}$ (squares, dashed lines). a, c L- $\left[{ }^{3} \mathrm{H}\right]$ glutamate. b, d $\left[{ }^{14} \mathrm{C}\right]$ GABA. Representative release assays are shown; each assay was performed three times with similar results.

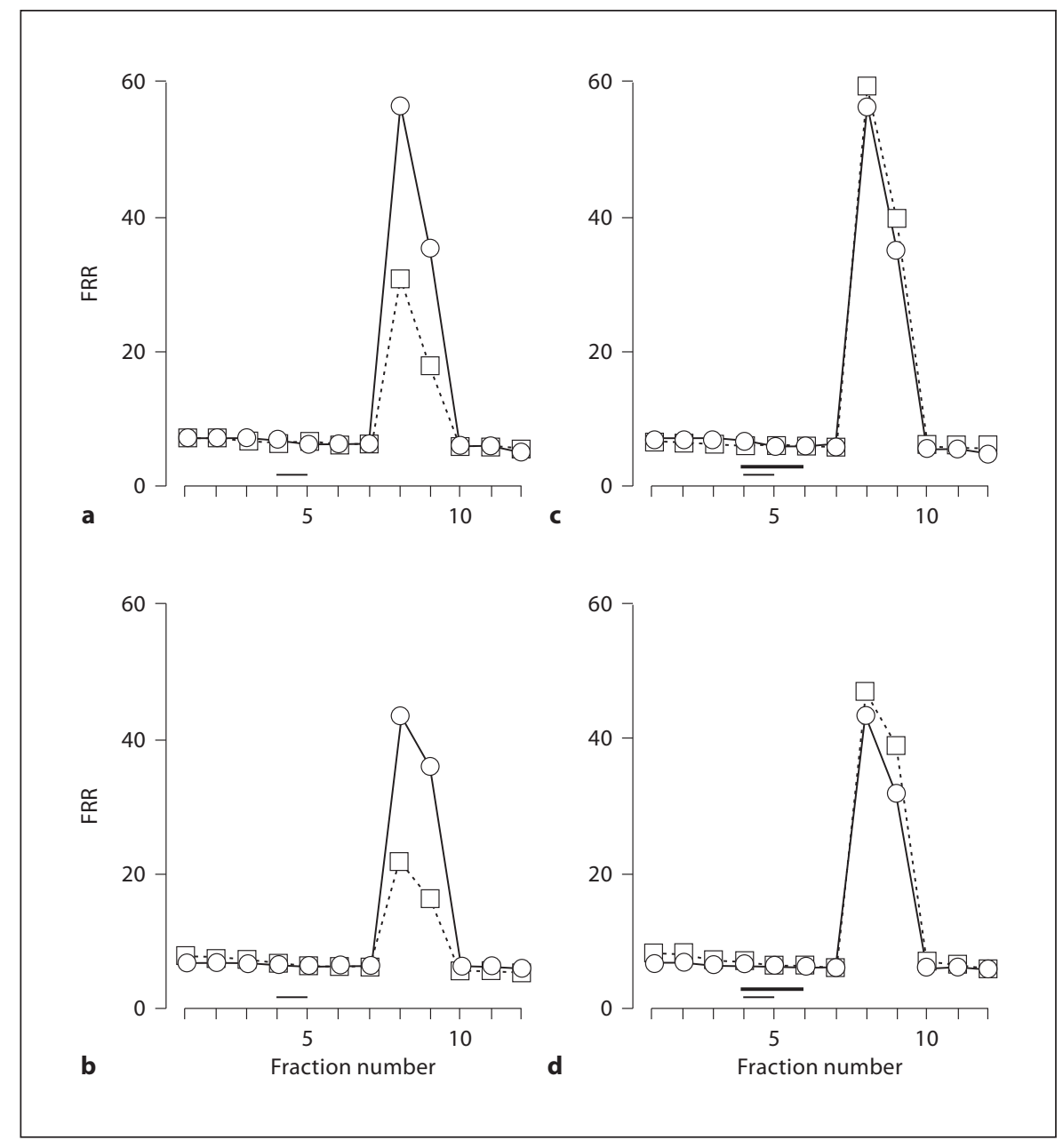

Fig. 3. $\mathrm{Ca}^{2+}$ dependence of release. a Mean AUC values for peaks elicited at the two $\mathrm{Ca}^{2+}$ ion concentrations were derived from the ANOVA used in figure 1d, e, averaged across both areas, all subjects, both transmitters, and peaks $\mathrm{P}_{1}$ and $\mathrm{P}_{2}$. The overall mean peak AUC in the presence of $2.5 \mathrm{mM} \mathrm{Ca}^{2+}$ ion concentration (PBC) was $189 \%$ of that in the absence of $\mathrm{Ca}^{2+}$ ions (PB0; main effect for $\mathrm{Ca}^{2+}$ significant, $\left.\mathrm{F}_{1,30}=181.375, \mathrm{p}<0.001\right)$. $\square=$ Release peak elicited in $0 \mathrm{mM} \mathrm{Ca}^{2+} ; \boldsymbol{\square}=$ release peak elicited in $2.5 \mathrm{mM}$ $\mathrm{Ca}^{2+}$; values are means \pm SEM on the FRR scale. $\mathbf{b}$ Comparison of the extent of enhancement of $\mathrm{L}-\left[{ }^{3} \mathrm{H}\right]$ glutamate and $\left[{ }^{14} \mathrm{C}\right] \mathrm{GABA}$ release by $\mathrm{Ca}^{2+}$. $\mathrm{L}-\left[{ }^{3} \mathrm{H}\right]$ glutamate release AUC in $\mathrm{PBC}$ averaged $203 \%$ of the AUC in PBO, whereas $\left[{ }^{14} \mathrm{C}\right] \mathrm{GABA}$ release AUC in PBC averaged $175 \%$ of the AUC in PB0 $\left(\mathrm{Ca}^{2+} \times\right.$ amino acid interaction significant, $\left.F_{1,30}=23.670, p<0.001\right)$. Key as in a. c-f Regressions on potential confounds. To delineate the vesicular component of release, peaks evoked in $\mathrm{PB} 0$ were subtracted from peaks evoked in PBC by the same stimulation event (either S1 or S2). To normalize these data, a different Kleczkowski transformation [24] was applied, given by $\kappa(\Delta)_{i j}=\log _{e}\left(\Delta_{i j}+25.194\right)$, where $\Delta_{i}$ is the AUC of the $i^{\text {th }}$ difference $(\mathrm{PBC}-\mathrm{PB} 0)$ peak elicited by stimulus $\mathrm{S}_{j}$. Values were regressed on the patient's age at death $(\mathbf{c}, \mathbf{d})$ or on the interval from death to autopsy (PMI; e, f). Scatterplots show individual $\kappa(\Delta)_{i j}$ values from each area (dorsolateral prefrontal cortex, DLPFC; primary motor cortex, PMC) of subjects undifferentiated for alcoholic status or liver pathology. Circles = DLPFC, $\mathrm{P}_{1}$; squares $=\mathrm{PMC}_{1}$; triangles $=\mathrm{DLPFC} \mathrm{P}_{2}$; inverted triangles $=$ $\mathrm{PMC}_{2}$. c, e L- $\left[{ }^{3} \mathrm{H}\right]$ glutamate. $\mathbf{d}, \mathbf{f}\left[{ }^{14} \mathrm{C}\right] \mathrm{GABA}$. Solid lines = regressions averaged across areas in $\mathrm{P}_{1}$; dashed lines = regressions averaged across areas in $\mathrm{P}_{2}$. Regression statistics: $\mathrm{L}-\left[{ }^{3} \mathrm{H}\right]$ glutamate on age, $\mathrm{P}_{1}: \mathrm{r}^{2}=0.045, \mathrm{p}=0.24 ; \mathrm{L}-\left[{ }^{3} \mathrm{H}\right]$ glutamate on age, $\mathrm{P}_{2}: \mathrm{r}^{2}=0.216$, $\mathrm{p}=0.007 ;\left[{ }^{14} \mathrm{C}\right] \mathrm{GABA}$ on age, $\mathrm{P}_{1}: \mathrm{r}^{2}=0.084, \mathrm{p}=0.11 ;\left[{ }^{14} \mathrm{C}\right] \mathrm{GABA}$ on age, $\mathrm{P}_{2}: \mathrm{r}^{2}=0.003, \mathrm{p}=0.77 ; \mathrm{L}-\left[{ }^{3} \mathrm{H}\right]$ glutamate on PMI, $\mathrm{P}_{1}: \mathrm{r}^{2}=$ $0.007, \mathrm{p}=0.65$; L- $\left.{ }^{3} \mathrm{H}\right]$ glutamate on PMI, $\mathrm{P}_{2}: \mathrm{r}^{2}=0.007, \mathrm{p}=0.65$; $\left[{ }^{14} \mathrm{C}\right] \mathrm{GABA}$ on PMI, $\mathrm{P}_{1}: \mathrm{r}^{2}=0.011, \mathrm{p}=0.57 ;\left[{ }^{14} \mathrm{C}\right] \mathrm{GABA}$ on PMI, $\mathrm{P}_{2}: \mathrm{r}^{2}=0.056, \mathrm{p}=0.19$. No other regression, including those restricted to a single cortical area or to a single group of subjects, achieved statistical significance. 


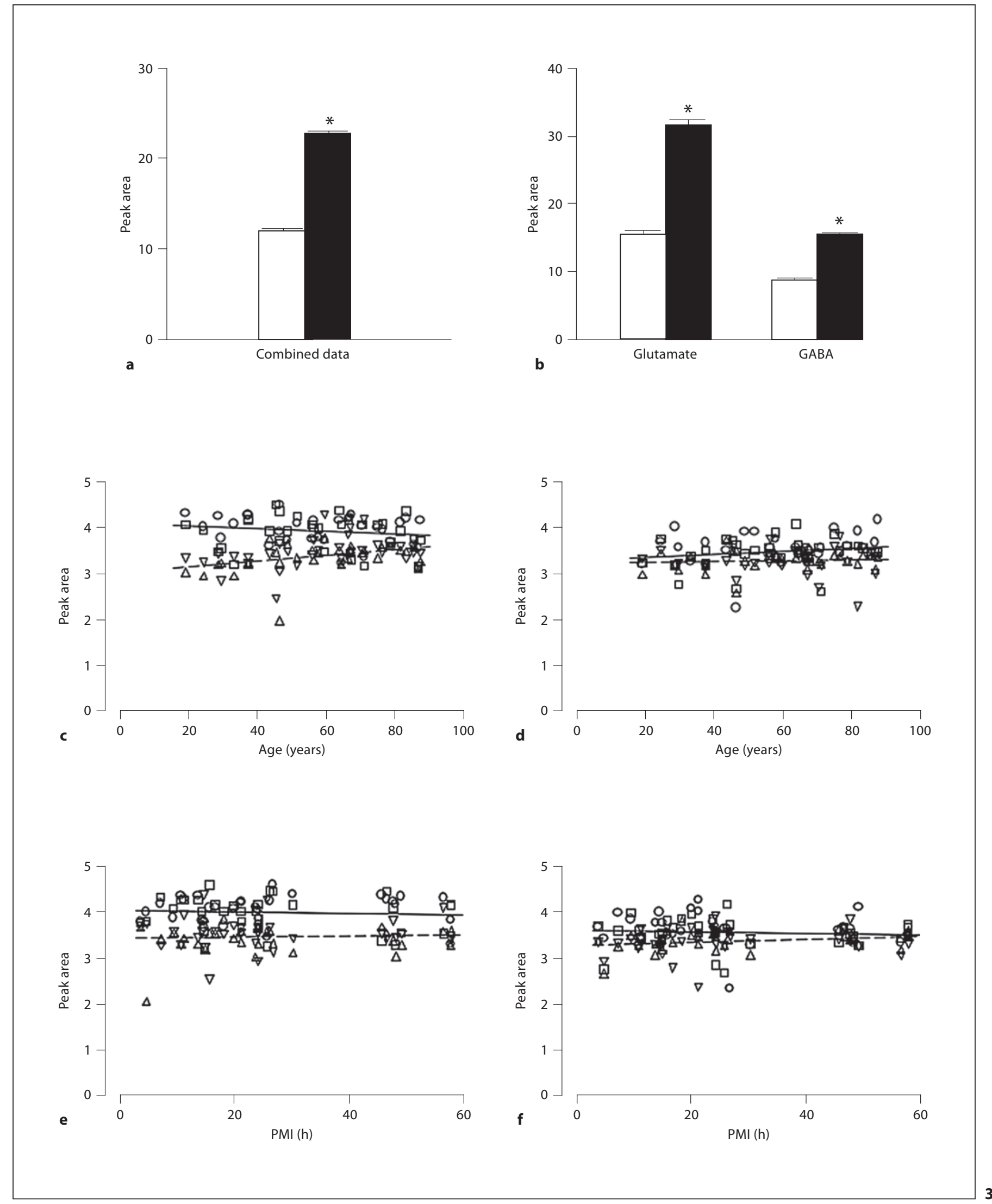

Effects of Alcohol Misuse on the

Neurosignals 2011;19:117-127 


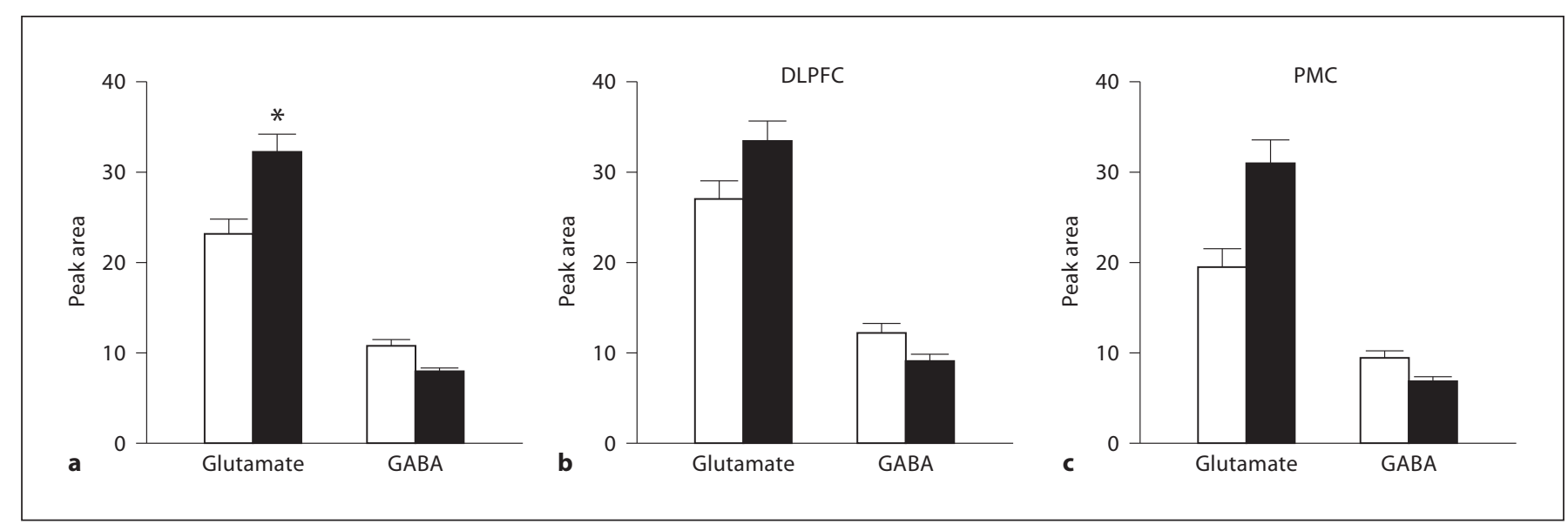

Fig. 4. Effect of alcohol misuse on $\mathrm{Ca}^{2+}$-dependent release. An ANOVA restricted to $\mathrm{P}_{1}$ difference $(\mathrm{PBC}-\mathrm{PB} 0)$ peak transforms $\left[\kappa(\Delta)_{i 1}\right.$ values] showed that electrical stimulation elicited vesicular $\left.\mathrm{L}-{ }^{3} \mathrm{H}\right]$ glutamate release more strongly than it elicited vesicular $\left[{ }^{14} \mathrm{C}\right] \mathrm{GABA}$ release (main effect for amino acid significant, $\mathrm{F}_{1,30}=$ $54.426, \mathrm{p}<0.001$ ). a Overall comparison between controls and alcoholics undifferentiated by comorbid cirrhosis. Release peak AUC values were averaged across brain regions. $\mathrm{Ca}^{2+}$-dependent stimulus-evoked L- $\left[{ }^{3} \mathrm{H}\right]$ glutamate release was greater in combined alcoholic than in nonalcoholic subjects, but $\left[{ }^{14} \mathrm{C}\right] \mathrm{GABA}$ release was not (alcoholic misuse status $\times$ amino acid interaction significant, $\left.\mathrm{F}_{1,30}=4.889, \mathrm{p}=0.035\right)$. Post-hoc testing by the NewmanKeuls method showed that the difference between groups ap- proached significance for $\mathrm{L}-\left[{ }^{3} \mathrm{H}\right]$ glutamate release, $\mathrm{p}=0.065$, but not for $\left[{ }^{14} \mathrm{C}\right] \mathrm{GABA}$ release, $\mathrm{p}=0.37$. In a separate ANOVA where subjects were further divided by gender, profiles did not vary significantly between males and females (not shown; alcoholic status $\times$ sex $\times$ amino acid interaction not significant, $\mathrm{F}_{1,28}=0.568, \mathrm{p}=$ 0.46). In fact, no term involving gender was significant in that ANOVA, $p>0.45$. b, $\mathbf{c}$ Release peak AUC values in each brain region. Regional profiles did not vary significantly from the overall pattern (alcohol-misuse status $\times$ amino acid $\times$ area interaction not significant, $\left.\mathrm{F}_{1,30}=0.329, \mathrm{p}=0.57\right) . \square=$ Nonalcoholic control subjects; $\mathbf{\square}=$ alcoholic subjects. Values are means \pm SEM on the FRR scale. stronger in alcohol-misusing subjects than in controls (fig. 4a). In contrast, $\left[{ }^{14} \mathrm{C}\right] \mathrm{GABA}$ release trended lower in alcoholics, although the effect was not significant (fig. 4a). The net effect would be to changetheexcitatory:inhibitory input to postsynaptic neurons. This pattern was not restricted to the dorsolateral prefrontal cortex (fig. $4 \mathrm{~b}, \mathrm{c}$ ): the enhancement in $\mathrm{L}-\left[{ }^{3} \mathrm{H}\right]$ glutamate release was as strong in the relatively spared primary motor cortex. This lack of regional specificity also applied to the following analyses (fig. 5 legend).

\section{Interactions with Cirrhosis and Gender}

Subjects were further divided by the presence of comorbid liver cirrhosis and/or by gender. This produced contrasting effects with the two transmitters. The release of L- $\left[{ }^{3} \mathrm{H}\right]$ glutamate showed an increasing trend, with cirrhotic alcoholics $>$ noncirrhotic alcoholics $>$ controls (fig. 5a). The data on cirrhotic alcoholics must be treated with caution because of the sample size. No pairwise difference was significant by post-hoc testing (fig. 5 legend), but independent confirmation of the trend was seen when male and female subjects were analyzed separately (fig. 5b, c); both sexes showed the same graded response. In contrast, $\left[{ }^{14} \mathrm{C}\right] \mathrm{GABA}$ release was markedly attenuated in alcoholics without comorbid disease but significantly enhanced in cirrhotic alcoholics (fig. 5a legend). The greater number of noncirrhotic alcoholics underpinned the overall reduction in $\left[{ }^{14} \mathrm{C}\right] \mathrm{GABA}$ release in alcoholics (fig. 4a). The data on cirrhotic alcoholics must be treated with caution because of the sample size, but it is noteworthy that the same trends were seen in independent analyses of male and female subjects (fig. 5b, c). The lack of male-female differences also applied to the previous analyses (fig. 4 legend).

\section{Discussion}

The primary accomplishment of the present study was to develop and optimize a paradigm to study the $\mathrm{Ca}^{2+}$ dependent stimulus-evoked release of amino acid neurotransmitters from synaptosomes prepared from human brain obtained at autopsy. Short trains of electrical pulses elicited brief pulses of preloaded L- $\left[{ }^{3} \mathrm{H}\right]$ glutamate 


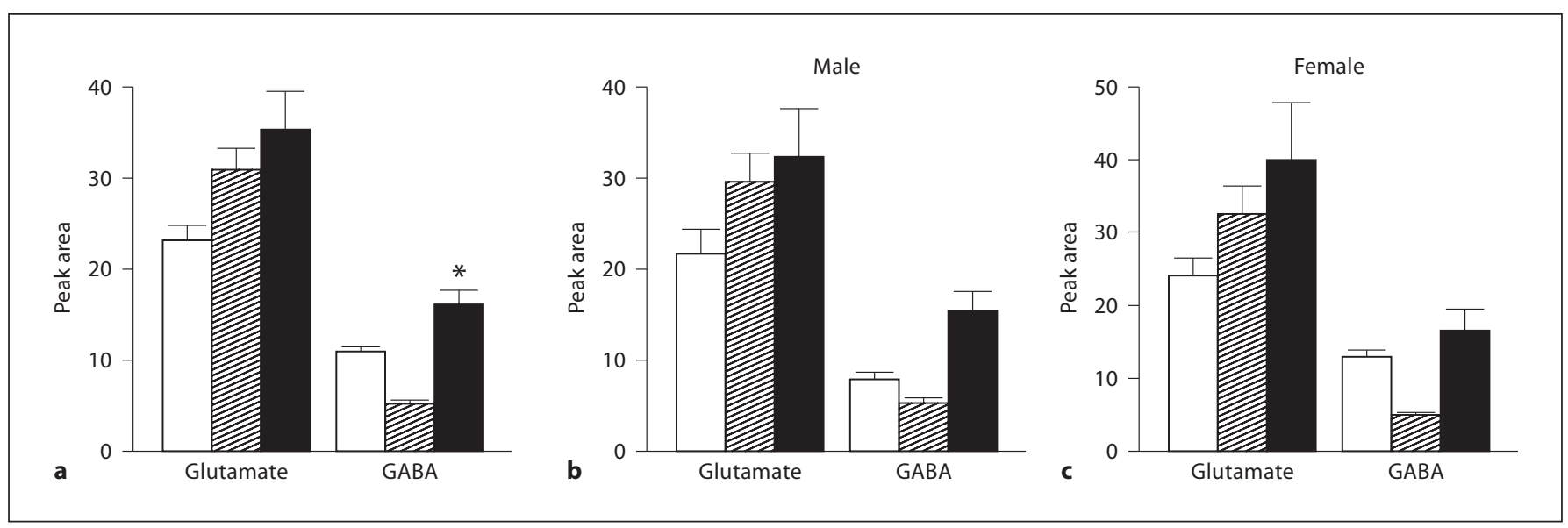

Fig. 5. $\mathrm{Ca}^{2+}$-dependent release in subjects divided by alcohol misuse status and cirrhosis. An ANOVA restricted to $\mathrm{P}_{1}$ difference (PBC - PB0) peak transforms $\left[\kappa(\Delta)_{i 1}\right.$ values] was performed. a Release peak AUCs averaged across brain regions. L- $\left[{ }^{3} \mathrm{H}\right]$ glutamate release was graded by disease severity, whereas the pattern $\left[{ }^{14} \mathrm{C}\right] \mathrm{GABA}$ release was biphasic (group $\times$ amino acid interaction significant, $\left.\mathrm{F}_{2,29}=3.476, \mathrm{p}=0.044\right)$. Post-hoc testing by the Newman-Keuls method showed that no pairwise difference between groups was significant for $\mathrm{L}-\left[{ }^{3} \mathrm{H}\right]$ glutamate release $(\mathrm{p}>0.15)$; $\left[{ }^{14} \mathrm{C}\right] \mathrm{GABA}$ release differed between alcoholics without comorbid disease and alcoholics with cirrhosis $(\mathrm{p}=0.036)$ but on no other

and $\left[{ }^{14} \mathrm{C}\right] \mathrm{GABA}$. The manner in which the autopsy tissue was collected, frozen, and thawed is critical for the preparation of viable synaptosomes $[10,11]$. The data shown here suggest that electrically evoked transmitter release was a physiological response rather than the result of lysis of the synaptosomes. The release peaks were self-limiting (no increase in peak duration with a 3-min stimulus compared with a 1.5 -min stimulus), and a second stimulus after a rest period evoked an additional release peak. These responses also confirm that the synaptosomes had developed membrane potentials upon incubation, as we have noted previously [18]. Radiolabeled transmitters enter synaptosomes via plasma membrane $\mathrm{Na}^{+}$-coupled transporters [19], and may then transit to synaptic vesicles [27]. Both uptake processes are energy dependent, because the transmitters are taken up against concentration gradient $[19,27]$. We have previously shown that the plasma-membrane glutamate and GABA transporters, and the intrasynaptosomal vesicular glutamate transporter, are functional in human synaptosomes prepared in the manner used here $[14,15,28]$.

A component of electrically evoked release was dependent on the presence of $\mathrm{Ca}^{2+}$ ions, which is considered to be an essential feature of vesicular stimulus-secretion between-group pairwise comparison $(\mathrm{p}>0.15)$. Regional profiles did not vary significantly from the overall pattern (not shown; group $\times$ amino acid $\times$ area interaction not significant, $F_{2,29}=$ $0.651, \mathrm{p}=0.53)$. b, $\mathbf{c}$ In a separate ANOVA, subjects were further divided by gender. Profiles did not vary significantly between males and females (group $\times$ sex $\times$ amino acid interaction not significant, $\mathrm{F}_{2,26}=0.248, \mathrm{p}=0.78$ ). In fact, no term involving gender was significant in the ANOVA, $p>0.25 . \square=$ Nonalcoholic control subjects; $\mathbb{Q}=$ alcoholics without comorbid disease; $\square=$ alcoholics with cirrhosis. Values are means \pm SEM on the FRR scale.

coupling [29]. The release peak elicited in $\mathrm{Ca}^{2+}$-free medium was smaller, but not zero. It is possible that electrical stimulation induced $\mathrm{Ca}^{2+}$ release from intracellular stores, or that the sequestering of $\mathrm{Ca}^{2+}$ by EGTA in the $\mathrm{Ca}^{2+}$-free buffer was incomplete. However, the most likely source of the $\mathrm{Ca}^{2+}$-free peak is reversal of the plasmamembrane transporters [30]. Our previous work showed that ionic concentration-effect curves for glutamate and GABA transport are much steeper in human than in rat synaptosomes [31], which suggests that changes in transmembrane ionic gradients will more markedly increase reverse transport in human preparations. Background non- $\mathrm{Ca}^{2+}$-dependent release hindered development of a vesicular exocytosis paradigm based on $\mathrm{K}^{+}$-induced depolarization [32]. Attempts to wash out the intrasynaptosomal cytoplasmic pool of radiolabel with a pulse-chase protocol, or to circumvent transporter reversal by utilizing 4-aminopyridine as the stimulus, proved unsatisfactory [33]. Depolarization-induced increase in respiration, which is likely to track closely with depolarization-evoked vesicular transmitter release, shows a more marked decline post-mortem than does transmitter uptake [18, 31]: vesicular exocytosis is a multi-component process, whereas uptake requires the integrity of a single protein 
complex [19]. This may have aided the current paradigm, where there was only modest decline in $\mathrm{Ca}^{2+}$-dependent release with increasing postmortem delay, because the radiolabel would only be taken up by viable synaptosomes.

The first L- $\left[{ }^{3} \mathrm{H}\right]$-glutamate release peak was higher in chronic alcoholics than in controls. This might reflect a difference in glutamate concentration in the nerve-ending cytoplasm. The concentrations of small molecular weight components can change markedly after death [18]: the levels achieved in synaptosomes after ex vivo incubation depend on reestablishment of membrane potentials coupled with metabolic processes supported by active respiration and glucose metabolism $[34,35]$. We found no differences in radiolabeled glutamate or GABA uptake between severe alcoholic cases and controls in previous studies [36]. Enhanced L- $\left[{ }^{3} \mathrm{H}\right]$-glutamate release in chronic alcoholics did not comport with cellular neuropathology. Rather than mirroring or underpinning localized neuronal loss, it may obliquely reflect the widespread loss of dendritic spines in the brain of the chronic alcoholic [37], because surviving, more robust, synaptic boutons would retain functional transporters that could take up $\mathrm{L}-\left[{ }^{3} \mathrm{H}\right]$-glutamate. Glutamate concentration is elevated in the brains of rats chronically administered ethanol [38, 39]. These studies were carried out on whole brain or brain slices, and did not distinguish the vesicular and metabolic compartments. The effect of chronic alcohol administration on the level of glutamate within nerve terminals was not determined.

Cirrhosis is a surrogate for alcohol misuse severity in that its prevalence correlates strongly with consumption [40], and this was true for the subjects in this study (see 'Methods'). The manifestation of glutamate-NMDA receptors in alcoholics is markedly affected by comorbid disease. Noncirrhotic alcoholics vary minimally from controls, whereas cirrhotic alcoholics differ from both of these groups in showing changes in receptor-binding parameters indicative of reduced receptor efficacy, and lower subunit transcript expression levels [16, 41, 42]. Reduced subunit transcript expression was found in both cortical regions. These observations are consonant with the finding that glutamate release increased with cirrhosis/severity, because it would be expected that increased availability of glutamate in the synapse would lead to downregulation of its receptors on the post-synaptic neuron [43]. In contrast, several studies have shown that chronic ethanol administration causes a significant decrease in the $\mathrm{K}^{+}$-induced release of $\mathrm{L}-\left[{ }^{3} \mathrm{H}\right]$-glutamate and endogenous L-glutamate from rat brain terminals [39, 44]. As well as possible species differences and variations in release paradigms [45], this mode of eliciting release results in significant reversal of the glutamate transporter (see above) [30].

The densities of $\mathrm{GABA}_{\mathrm{A}}$ receptors in human alcoholics depend critically on cirrhosis of the liver. $B_{\mathrm{MAX}}$ is significantly higher in noncirrhotic alcoholics than in controls, but does not differ between cirrhotic alcoholics and controls [5], or in hepatic encephalopathy patients who had acquired cirrhosis through alcohol misuse but abstained from alcohol for at least 6 months prior to death [46]. Chronic ethanol administration reportedly does not alter GABA concentrations in synaptosomes isolated from rat frontal cortex [47]. In the present study, $\left[{ }^{14} \mathrm{C}\right] \mathrm{GABA}$ release did not differ between cirrhotic alcoholics and controls, consistent with the $\mathrm{GABA}_{\mathrm{A}} \mathrm{B}_{\mathrm{MAX}}$ data in those subjects noted above, although this must be treated with caution due to the limited availability of cases. The reduced synaptosomal $\left[{ }^{14} \mathrm{C}\right] \mathrm{GABA}$ release data in alcoholics without comorbid disease is consistent with the significant upregulation of $\mathrm{GABA}_{\mathrm{A}}$ receptors in the same subjects.

\section{Acknowledgments}

We are grateful to Neuropathologists from the Queensland Brain Bank, SCMB, University of Queensland, and from the NSW Tissue Resource Centre for providing tissue samples, and to the next of kin for informed written consent for the studies. The tissue banks are part of Australian Brain Bank Network supported by the National Health and Medical Research Council (NHMRC). The NSW Centre and Australian Brain Donor Program are supported by The University of Sydney, NHMRC, Schizophrenia Research Institute, National Institutes of Alcoholism and Alcohol Abuse USA (NIAAA), and NSW Department of Health. Financial support was provided by the NIAAA under grant NIH AA12404 and the NHMRC under grant No. 401551.

References

1 Harper CG, Matsumoto I: Ethanol and brain damage. Curr Opin Pharmacol 2005;5:7378.

-2 Kril JJ, Harper CG: Neuronal counts from four cortical regions of alcoholic brains. Acta Neuropathol (Berlin) 1989;79:200-204.

- 3 Kril JJ, Halliday GM, Svoboda MD, Cartwright $\mathrm{H}$ : The cerebral cortex is damaged in chronic alcoholics. Neuroscience 1997;79: 983-998.

4 Dodd PR, Thomas GJ, Harper CG, Kril JJ: Amino acid neurotransmitter receptor changes in cerebral cortex in alcoholism: effect of cirrhosis of the liver. J Neurochem 1992;59:1506-1515. 
5 Thomas GJ, Dodd PR: Transmitter amino acid neurochemistry in chronic alcoholism with and without cirrhosis of the liver. Drug Alcohol Rev 1993;12:91-98.

6 Lewohl JM, Crane DI, Dodd PR: Alcohol, alcoholic brain damage, and $\mathrm{GABA}_{\mathrm{A}}$ receptor isoform gene expression. Neurochem Int 1996;29:677-684

7 Lewohl JM, Wang L, Miles MF, Zhang L, Dodd PR, Harris RA: Gene expression in human alcoholism: microarray analysis of frontal cortex. Alcohol Clin Exp Res 2000; 24:1873-1882.

8 Mayfield RD, Lewohl JM, Dodd PR, Herlihy A, Liu J, Harris RA: Patterns of gene expression are altered in the frontal and motor cortices of human alcoholics. J Neurochem 2002;81:802-813.

9 Liu J, Lewohl JM, Dodd PR, Randall PK, Harris RA, Mayfield RD: Gene expression profiling of individual cases reveals consistent transcriptional changes in alcoholic human brain. J Neurochem 2004;90:10501058.

10 Hardy JA, Dodd PR, Oakley AE, Perry RH, Edwardson JA, Kidd AM: Metabolically active synaptosomes can be prepared from frozen rat and human brain. J Neurochem 1983; 40:608-614.

-11 Dodd PR, Hardy JA, Baig EB, Kidd AM, Bird ED, Watson WEJ, Johnston GAR: Optimization of freezing, storage, and thawing conditions for the preparation of metabolically active synaptosomes from frozen rat and human brain. Neurochem Pathol 1986;4: 177-198.

-12 Deutsch C, Drown C, Rafalowska U, Silver IA: Synaptosomes from rat brain: morphology, compartmentation, and transmembrane $\mathrm{pH}$ and electrical gradients. J Neurochem 1981;36:2063-2072.

13 Tibbs GR, Dolly JO, Nicholls DG: Evidence for the induction of repetitive action potentials in synaptosomes by $\mathrm{K}^{+}$-channel inhibitors: an analysis of plasma membrane ion fluxes. J Neurochem 1996;67:389-397.

-14 Hardy JA, Barton AJL, Lofdahl E, Cheetham SC, Johnston GAR, Dodd PR: Uptake of $\gamma$ aminobutyric acid and glycine by synaptosomes from postmortem human brain. J Neurochem 1986;47:460-467.

15 Westphalen RI, Scott HL, Dodd PR: Synaptic vesicle transport and synaptic membrane transporter sites in excitatory amino acid nerve terminals in Alzheimer disease. J Neural Transm 2003;110:1013-1027.

-16 Ridge JP, Dodd PR: Cortical NMDA receptor expression in human chronic alcoholism: influence of the TaqIA allele of ANKK1. Neurochem Res 2009;34:1775-1782.

$\checkmark 17$ Lieber CS: Prevention and treatment of liver fibrosis based on pathogenesis. Alcohol Clin Exp Res 1999;23:944-949.
18 Hardy JA, Dodd PR: Metabolic and functional studies on post-mortem human brain. Neurochem Int 1983;5:253-266.

19 Danbolt NC: Glutamate uptake. Prog Neurobiol 2001;65:1-105.

20 Bradford HF: Metabolic response of synaptosomes to electrical stimulation: release of amino acids. Brain Res 1970;19:239-247.

21 Kuo S-W, Dodd PR: Stimulus-coupled amino acid transmitter release in human alcoholics. Proc Aust Neurosci Soc 2005;16:33.

22 Kuo S-W, Dodd PR: Electrically-evoked neurotransmitter release in relation to alcoholism. J Neurochem 2006;98(suppl 1):34.

23 Dodd PR, Hardy JA, Oakley AE, Edwardson JA, Perry EK, Delaunoy J-P: A rapid method for preparing synaptosomes: comparison with alternative procedures. Brain Res 1981; 226:107-118.

24 Kleczkowski A: The transformation of local lesion counts for statistical analysis. Ann Appl Biol 1949;36:139-152.

25 Winer BJ, Brown DR, Michels KM: Statistical Principles in Experimental Design, ed 3. Sydney, McGraw-Hill, 1991.

26 Bradford HF: Cerebral cortex slices and synaptosomess: in vitro approaches to brain metabolism; in Fried R (ed): Methods of Neurochemistry. New York, Marcel Dekker, 1972 vol 3, pp 155-202.

27 Liu Y, Edwards RH: The role of vesicular transport proteins in synaptic transmission and neural degeneration. Annu Rev Neurosci 1997;20:125-156.

28 Cowburn RF, Dodd PR, Hardy JA, Johnston GAR: A comparison of high affinity synaptosomal uptake of D-aspartate in rat and human brain. Neurochem Int 1987;3:339-346.

29 Rubin RP: The role of calcium in the release of neurotransmitter substances and hormones. Pharmacol Rev 1970;22:389-428.

30 Levi G, Raiteri M: Carrier-mediated release of neurotransmitters. Trends Neurosci 1993 16:415-419.

31 Dodd PR, Watson WEJ, Morrison MM Johnston GAR, Bird ED, Cowburn RF, Hardy JA: Uptake of $\gamma$-aminobutyric acid and L-glutamic acid by synaptosomes from postmortem human cerebral cortex: multiple sites, sodium dependence and effect of tissue preparation. Brain Res 1989;490:320-331.

32 Kuo S-W, Dodd PR: GABA and glutamate neurotransmitter release in the cerebral cortex of human chronic alcoholics. Proc Aust Neurosci Soc 1999;10:206.

33 Kuo S-W, Dodd PR: Development of a paradigm for the study of amino acid neurotransmitter release in human autopsy brain samples. Proc Aust Neurosci Soc 2001;12:126.

34 Nicholls DG, Attwell D: The release and uptake of excitatory amino acids. Trends Pharmacol Sci 1990;11:462-468.
35 Choi SW, Gerencser AA, Nicholls DG: Bioenergetic analysis of isolated cerebrocortical nerve terminals on a microgram scale: Spare respiratory capacity and stochastic mitochondrial failure. J Neurochem 2009;109: 1179-1191.

36 Dodd PR, Kril JJ, Thomas GJ, Watson WEJ, Johnston GAR, Harper CG: Receptor binding sites and uptake activities mediating GABA neurotransmission in chronic alcoholics with Wernicke encephalopathy. Brain Res 1996;710:215-228.

37 Harper CG, Kril JJ: Neuropathology of alcoholism. Alcohol Alcohol 1990;25:207-216.

38 Ledig M, M'Paria JR, Mandel P: Free amino acids in the brain of ethanol treated rats. Subst Alcohol Actions Misuse 1982;3:25-30.

-39 Keller E, Cummins JT, von Hungen K: Regional effects of ethanol on glutamate levels, uptake and release in slice and synaptosome preparations from rat brain. Subst Alcohol Actions Misuse 1983;4:383-392.

40 Saunders JB, Latt N: Epidemiology of alcoholic liver disease; in Hayes PC (ed): Clinical Gastroenterology. Sydney, Ballière Tindall, 1993, pp 555-579.

41 Dodd PR, Foley PF, Buckley ST, Eckert AL, Innes DJ: Genes and gene expression in the brain of the alcoholic. Addict Behav 2004;29: 1295-1309.

42 Ridge JP, Ho AM-C, Innes DJ, Dodd PR: The expression of NMDA receptor subunit mRNA in human chronic alcoholics. Ann NY Acad Sci 2008;1139:10-19.

43 Albrecht J, Jones EA: Hepatic encephalopathy: molecular mechanisms underlying the clinical syndrome. J Neurol Sci 1999;170: 138-146.

44 Sabria J, Torres D, Pasto M, Peralba JM, Allali-Hassani A, Pares X: Release of neurotransmitters from rat brain nerve terminals after chronic ethanol ingestion: differential effects in cortex and hippocampus. Addict Biol 2003;8:287-294.

45 Muzzolini A, Bregola G, Bianchi C, Beani L, Simonato M: Characterization of glutamate and $\left[{ }^{3} \mathrm{H}\right] \mathrm{D}$-aspartate outflow from various in vitro preparations of the rat hippocampus. Neurochem Int 1997;31:113-124.

-46 Butterworth RF, Lavoie J, Giguère JF, Pomier-Layrargues G: Affinities and densities of high-affinity $\left.{ }^{3} \mathrm{H}\right]$ muscimol $\left(\mathrm{GABA}_{\mathrm{A}}\right)$ binding sites and of central benzodiazepine receptors are unchanged in autopsied brain tissue from cirrhotic patients with hepatic encephalopathy. Hepatology 1988;8:10841088

47 Frye GD, Fincher AS: Effect of ethanol on $\gamma$ vinyl GABA-induced GABA accumulation in the substantia nigra and on synaptosomal GABA content in six rat brain regions. Brain Res 1988;449:71-79. 